\section{SOI: $1.1 /$ TAS DOI: $10.15863 /$ TAS International Scientific Journal Theoretical \& Applied Science}

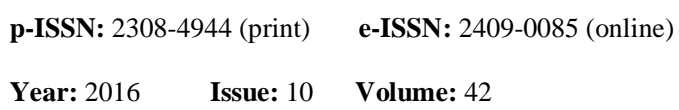

SECTION 21. Pedagogics. Psychology. Innovation in the field of education.

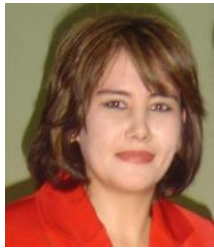

Sanobar Narzikulovna Akbarova

$\mathrm{PhD}$, ass. prof., Tashkent Pediatric Medical Institute, department of Foreign languages, Pedagogic and Psychology; Uzbekistan sanobarakbarova@tashpmi.uz

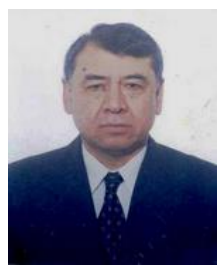

Talat Saidalimovich Agzamhodjayev $\mathrm{PhD}$, prof., Tashkent Pediatric Medical Institute, department of Anesthesiology and Intensive Care; Uzbekistan

Bahrom Hodja-Kammajdinovich Ayhodjayev $\mathrm{PhD}$, ass. prof., Tashkent Pediatric Medical Institute, department of Biological Chemistry, Bioinorganic and Bioorganic

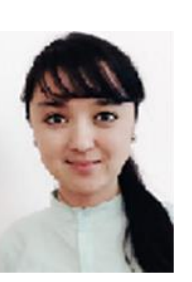
Chemistry; Uzbekistan

Shoira Ismoilovna Turdiyeva student Tashkent Pediatric Medical Institute; Uzbekistan

Mehribon Khabibjonovna Alimova student

Tashkent Pediatric Medical Institute; Uzbekistan

\title{
GENDER DISTINCTIONS IN RESULTS OF CATTELL'S 16PF QUESTIONNAIRE AT STUDENTS OF MEDICAL INSTITUTE
}

\begin{abstract}
Many research work of scientists deal with study gender personal characteristics. We investigated gender distinction in the personal traits of students in Tashkent Pediatric Medical Institute. Participants (239 females and 225 males) were the first year students. Cattell's 16 PF Questionnaire was used. Our research results were not coincide with other scientist's results: the females were higher than males in factors $E$ (Dominance), $N$ (Privateness) at $P<0,001$ and L (Vigilance) at $P<0,01 . M$ (Abstractedness) and Q3 (Perfectionism) factors' general average points of female were less at $P<0,01$.

Interrelation correlation between factors $16 \mathrm{PF}$ Questionnaire showed gender differences, especially connection between E-F, E-H factors at females were significantly closely than male's one at $P<0,01$. So, the structure of personality traits of females is more co-ordinated and that of male's one is more integrated. We recommended performing researches due to gender distinction with researchers of both sex, in order to eliminate the influencing factor of researcher's sex at participants and results.

Key words: psychological treats, gender, psychology of personality, Cattell R.B., 16PF Questionnaire.

Language: English

Citation: Akbarova SN, Agzamhodjayev TS, Ayhodjayev BH, Turdiyeva SI, Alimova MK (2016) GENDER DISTINCTIONS IN RESULTS OF CATTELL'S 16PF QUESTIONNAIRE AT STUDENTS OF MEDICAL INSTITUTE. ISJ Theoretical \& Applied Science, 10 (42): 95-99.

Soi: http://s-o-i.org/1.1/TAS-10-42-20 Doi: crossef http://dx.doi.org/10.15863/TAS.2016.10.42.20

UDC 159.923 .3

\section{Introduction}

Due to long-term works of scientists in psychology, such as Cattell, could reveal steady personal features in persons. The aspiration of this famous scientist to systematise personal traits, like

the Mendeleev's table of chemical elements, has led to creation tests, known nowadays and called as his name. One of them was intended to study 16factorial personal traits (Cattell,1979; Cattell,1980) $[1,2]$ those are invariable for 50 years of researches.
\end{abstract}


Cattell's sixteen unitary traits of the $16 \mathrm{PF}$ Questionnaire were used in studying of various professional traits (Pulkina, 2010; Berebin Condratenkov, 2012; Sokolova, 2011) [3-5], a psychological picture of various diseases (Volkova, Sukalo, 2005) [6] and other profiles. The 16factorial test of Cattell also, gave possibility to study of gender distinctions in personal character traits.

«A gender in psychology is the sociallybiological characteristic with help of that the people make definition of concepts «man» and «woman» (Bern, 2002) [7].

A lot of works were devoted to gender study of psychological features. For example, results of many scientists' works, such as Maccoby and Jacklin (1978); Feingold (1994), Eagly (1970), Lindholm (1999), Arkin (1927), Vagner (1929) who showed, gender distinctions was revealed under following personal characteristics:

"- Men were more assertive, dominating and had higher self-estimation, than women;

- Women surpassed in disturbing, trustfulness and ability to care and bring up others" (Bendas and Bedas, 2009) [8].

By of Schmitt, Realo, Voracek (2008) [9] who studied gender distinctions by the factors of Big Five in 55 nations, showed, that women had tendency to be a little above than men in neuroticism, extraversion, conformal and conscientiousness.

In medicine it is also possible to observe gender distinctions at choice of medical speciality. For example, $95 \%$ surgeons are men. Women with medical education preferred to work more in pediatrics sphere, neonatology, endocrinology, children's neurology etc. As it is known, professiogram of these specialities demanded peculiar personal features (Smolin, Loginova and Voight, 2013;) [10]. In connection with it the question «Were there gender distinctions in personal traits at students of Medical Institute? » could occur here. Our article deals with study of this question.

\section{Materials and Methods}

Our purpose was to study personal traits of students at medical institute from the point of view gender distinctions. Researches were at the Tashkent Pediatric Medical Institute. The objects of research were students of primary courses of all faculties (Pediatric, Therapy, Medical Pedagogy and Nursing). Testing was performed at the second term from 2014 to 2015 years. The age of respondents was from 19 to 21 years at the moment of testing. They were Uzbek nationality. In total, 464 students were tested (239 were females and 225 were males). The object of research was personal traits of students.

The objective was to reveal gender distinctions of personal features of students of Medical Institute, where the research concept was based on methodological principles of determinism, objectivity, relativity, systems (Gormin, 2010) [11].

Psychodiagnostical method as Cattell's 16PF Questionnaire (186 questions) was used to assess personality traits of students. The analysis of results was made in gender aspect. The mathematical statistical analysis was made by using the method of correlation.

\section{Results and discussion}

A. Gender distinctions concerning to separate factors of Cattell's 16 PF Questionnaire.

As it is known, all factors of Cattell's $16 \mathrm{PF}$ Questionnaire were discribed by dividing into two pole, where the pole of Low Range consists of 1-5 balls and other pole of High Range was for points 610 (Conn and Rieke, 1994) [12]. By comparing the general average balls concerning separate factors of males and females, we discovered several essential distinctions. Below we considered that all results were shown in the Table 1 in order of increase gender distinctions.

By the Table 1, there are no informative gender distinctions data concerning factors B (Reasoning), C (Emotional Stability), F (Liveliness), I (Sensitivity), $\mathrm{Q}_{1}$ (Openness to Change), $\mathrm{Q}_{2}$ (Self-Reliance), $\mathrm{Q}_{4}$ (Tension).

It can be seen in Table 1 gender distinctions were found in factors A (Warmth), G (RuleConsciousness), $\mathrm{H}$ (Social Boldness) and $\mathrm{O}$ (Apprehension); its, however were a little informative.

We consider that sex differences in factors L, M and $\mathrm{Q}_{3}$ are to be essential. For example, Table 1 demonstrates difference in the factor $\mathrm{L}$ named Vigilance. Inspite that, both genders were included in High Range pole of $\mathrm{L}$ factor, the difference in points differs considerably. Thereby, the females were more vigilant, suspicious, skeptical, distrustful and more oppositional than the males of investigated students. Apparently, these data didn't confirm the above presented data, where women were characterized as trustful ones (Bendas and Bedas, 2009) [8].

We related another gender distinction to factor M (Abstractedness). These data divided males to the pole of High Range and females to the pole of Low Range. According to description of $16 \mathrm{PF}$ Questionnaire (concerning $\mathrm{M}$ factor), our males can be assessed as abstract, imaginative, absent minded, impractical, absorbed in ideas, and, opposite traits like grounded, practical, prosaic, solution oriented, steady and conventional were used for female participants.

The last factor having considerable gender distinction at validity $\mathrm{P}<0,01$, we demonstrated in the Table 1, concerning factor $\mathrm{Q}_{3}$ (Perfectionism). Both sex groups were located in description of High Range pole, but the males were more perfectionistic, 
organized, compulsive, self-disciplined, socially precise, exacting will power, control, selfsentimental than females.

We have discovered significant sex differences being related to factors $\mathrm{E}$ and $\mathrm{N}$ at high validity. So, the data for males in $\mathrm{E}$ (Dominance) factor indicated the male participants as a bit deferential, cooperative, avoids conflict, submissive, humble, obedient, easily led, docile, accommodating. The female data surprised us with estimation being dominant, forceful, assertive, aggressive, competitive, stubborn, bossy. Dominating character of female especially was for Therapy faculty.

Besides the fact that $«$... existence of political, economic, religious and social divisions between the man and the woman, based on a traditional antithesis: the man is the mister, the woman is the patient martyr» (Bern, 2002) [7], our research showed female respondents as dominating, than the males ones. This information did not coincide with results of scientists Maccoby, Jacklin, Fejngold, Eagly, Lindholm, Arkin and Vagner that were above mentioned.

Also, we have got the highest gender distinction in our research, concerning factor $\mathrm{N}$ (Privateness). Females received point surpassed male's on 1,4 points, that provided us to ascertain about dividing the gender group into opposite pole of $\mathrm{N}$ factor. So that, the males were forthright, genuine, artless, open, guileless, naive, unpretentious and involved. The female participants, on the contrary, were private, discreet, nondisclosing, shrewd, polished, worldly, astute and diplomatic.

Apparently, some parties of our research, namely in factors $\mathrm{E}$ and $\mathrm{L}$ have contradicted works being mentioned by above authors. Fejngold also noticed that data on gender distinctions, received by means of supervision and personal tests, not always coincide. In some literature the sex of researcher was said, as «apparently, strongly influences the fact of detection of gender differences. Eagly and Carli concluded, that, the most likely, the scientists have tendency to plan, perform and state the researches in such way, that would flatter that gender, whom they belong» (Bern, 2002) [7]. Testing process in our research was made by woman (the 1-author of this article), but she had not any purposes to flatter the females. In the one hand, coinciding findings were related to our research, and, others can be explained by the next. We have just assumed that the studied females' sample of our research (in this case, in the first course of our institute) consisted of more females with dominating character. We have no information about "was it single instance or all Medical Institute have the same results?" On the other hand, we have additional assumption on influence of researchers' sex on the fact of detection of gender distinctions in favour of gender: in the process of research, mainly during getting data, the participants having the same sex as researcher feel themselves more comfortable and confident, than opposite sex. Therefore, the researches or, at least, testing process concerning studying of gender features must be pertinently provided by researchers of opposite sex. Thus, influence of researchers' gender on investigated objects will be same, and the factor of dominating influence of separate gender would be eliminated.

\section{B. Gender distinctions in interrelations of 16 PF Questionnaire's factors. \\ During the further analyses, we found out that} another aspect of gender distinctions concerning to Cattell's 16 PF Questionnaire. It was connected with correlation of 16 factors. We have studied correlation connection for the general sample, and separately for sample males and females. In the received results we focused our attention on the high indicators. As a result for the general sample we have observed considerable positive connections between factors A(Warmth)-H(Social-Boldness), A(Warmth)F(Liveliness), C(Emotional Stability)-H(SocialBoldness), E(Dominance) -L(Vigilance), $\mathrm{F}$ (Liveliness)-H(Social-Boldness), $\mathrm{O}$ (Apprehension) - $\mathrm{Q}_{4}$ (Tension) and negative relation between $\mathrm{C}$ (Emotional Stability)-O(Apprehension), $\mathrm{C}$ (Emotional Stability) - $\mathrm{Q}_{4}$ (Tension) factors (Table 2).

Further correlations between 16-factors were made separately for males and females participants. In difference from the general sample, the most considerable correlation connections were observed in addition with female sample. They concerned factors $\quad \mathrm{E}$ (Dominance) -H(Social-Boldness), $\mathrm{E}$ (Dominance) -F(Liveliness), $\mathrm{F}$ (Liveliness) $\mathrm{Q}_{2}$ (Self-Reliance), H(Social-Boldness)

$\mathrm{Q}_{4}\left(\right.$ Tension), L(Vigilance) - $\mathrm{Q}_{4}($ Tension) (Table 2).

The analysis of received considerable correlation interrelations of 16-factors in gender aspect showed that they had obvious gender distinction. Female sample showed big interrelations between factors being presented in Table 2 than in male sample. According to Table 2, all correlation values concerning females were more than at males. Some of them were even significant. For example, interrelation between factors $\mathrm{E}$ (Dominance) and $\mathrm{F}$ (Liveliness), E (Dominance) and $\mathrm{H}$ (SocialBoldness) had correlation values concerning males who were surpassed by females more than twice. Also, despite the relation between factors $\mathrm{H}$ (SocialBoldness) and $\mathrm{Q}_{4}$ (Tension) was negative, correlation revealed values at females were higher than male's by 1,4 times, and, it was essential difference.

In addition, we have studied the rest correlation results, it was $r<280$. The correlation of 16 factors, in general, gave us 136 various combinations of these factors. Deeply analyzing, we observed that only 51 combinations (from 136) showed males results more 
than females. So, according this data, we can conclude, that $62,5 \%$ interrelations between 16 factors of personality traits at our female students with medical education reflected more closely than of male's one.

Relying on these data, we can say, that structure of personality traits of investigated male students were more integrated, than at the females. Revealed stronger interferences between several factors at females, gave us possibility to assume, that the general personal structure at females was more organised and co-ordinated, than at males.

«Long time scientists considered, that the man is psychologically more healthy ... Now more prevalence has opinion, that the man's gender role can be a source of alarm and uneasiness because of some aspects are dysfunctional and inconsistent» (Bern, 2002) [7]. Our data showed that the females' psychology is arranged more harmoniously, than males. Approaches to personality from the point of traits view lead to revealing of base traits and creation of the Big Five. (Pervin, John, 2000) [13]. Thereby, scientists tried to structure psychological character traits in uniform system.

\section{Conclusion}

Gender distinctions, being received in our research, concerning interfactorial correlation connections, assume, that narrowness of connection between some factors depend on gender. But, there is a question "whether our data are single or not?» Additional researches can be the hope of answering this question. It is necessary to perform the same researches in other samples with participation of two researchers in both genders, eliminating dominating gender influence of the researcher on the investigated respondent.

Following the results of our research, we can conclude the following statements:

1. Female students of the 1-st course at Medical Institute (TashPMI) were more dominating, suspicious, practical, diplomatic and less supervise themselves, than males. The factors $\mathrm{E}$ and $\mathrm{N}$ are the most significant for gender distinction than any other factors.

2. There are gender distinctions in interfactorial connections in 16PF Questionnaire of Cattell $(\mathrm{A}-\mathrm{H}$, A-F, C-H, C-O, C-Q 4 , E-F, E-H, E-L, F-H, F-Q 2 , H$\mathrm{Q}_{4}, \mathrm{~L}-\mathrm{Q}_{4}$ and $\mathrm{O}-\mathrm{Q}_{4}$ ) for the investigated students. Hierarchical structure of many "Cattell's factors" at female students are shown much co-ordinated, having considerable correlation connection, than at males of the investigated participants.

3. The performance of researches concerning with gender distinctions study must be provided with researchers of both genders in order to eliminate effect of influence of researcher's sex on participants.

\section{Acknowledgments}

We thank a management and teachers TashPMI for the rendered help in realization of performance of our research.

Gender distinction in average points of16 PF Questionnaire.

Table 1

\begin{tabular}{|l|l|l|l|l|}
\hline № & Factors & $\begin{array}{l}\mu, \\
\text { male }\end{array}$ & \multicolumn{1}{c|}{$\begin{array}{c}\mu, \\
\text { female }\end{array}$} & $\begin{array}{c}\text { Validity } \\
(<\mathrm{P})\end{array}$ \\
\hline 1 & $\mathrm{~A}$ & $6,56 \pm 0,11$ & $6,12 \pm 0,11$ & 0,05 \\
\hline 2 & $\mathrm{~B}$ & $4,46 \pm 0,16$ & $4,32 \pm 0,14$ & \\
\hline 3 & $\mathrm{C}$ & $5,61 \pm 0,12$ & $5,62 \pm 0,11$ & 0,001 \\
\hline 4 & $\mathrm{E}$ & $4,96 \pm 0,11$ & $6,57 \pm 0,10$ & \\
\hline 5 & $\mathrm{~F}$ & $4,84 \pm 0,11$ & $5,05 \pm 0,11$ & 0,05 \\
\hline 6 & $\mathrm{G}$ & $5,12 \pm 0,10$ & $5,59 \pm 0,10$ & 0,05 \\
\hline 7 & $\mathrm{H}$ & $5,57 \pm 0,11$ & $5,93 \pm 0,11$ & \\
\hline 8 & $\mathrm{I}$ & $6,02 \pm 0,12$ & $6,31 \pm 0,13$ & 0,01 \\
\hline 9 & $\mathrm{~L}$ & $6,30 \pm 0,11$ & $7,55 \pm 0,10$ & 0,01 \\
\hline 10 & $\mathrm{M}$ & $5,35 \pm 0,12$ & $4,79 \pm 0,11$ & 0,001 \\
\hline 11 & $\mathrm{~N}$ & $4,49 \pm 0,13$ & $5,88 \pm 0,12$ & 0,05 \\
\hline 12 & $\mathrm{O}$ & $6,38 \pm 0,13$ & $6,79 \pm 0,11$ & \\
\hline 13 & Q1 & $6,14 \pm 0,13$ & $6,37 \pm 0,11$ & 0,01 \\
\hline 14 & Q2 & $5,96 \pm 0,11$ & $5,90 \pm 0,10$ & \\
\hline 15 & Q3 & $7,15 \pm 0,12$ & $6,32 \pm 0,12$ & \\
\hline 16 & Q4 & $5,94 \pm 0,11$ & $6,12 \pm 0,10$ & \\
\hline
\end{tabular}


Gender distinctions in interrelations between 16-factors of 16 PF Questionnaire.

\begin{tabular}{|l|l|l|l|l|l|}
\hline № & Factors & $\begin{array}{l}\text { General } \\
\text { examinees } \\
\text { (464 students) }\end{array}$ & $\begin{array}{l}\text { Males } \\
(225 \text { students })\end{array}$ & $\begin{array}{l}\text { Females } \\
(239 \text { students })\end{array}$ & $\begin{array}{l}\text { Validity of } \\
\text { gender } \\
\text { distinction, (P<) }\end{array}$ \\
\hline 1 & A-H & $\mathrm{r}=0,301$ & $\mathrm{r}=0,291 ;$ & $\mathrm{r}=0,345 ;$ & - \\
\hline 2 & $\mathrm{~A}-\mathrm{F}$ & $\mathrm{r}=0,328$ & $\mathrm{r}=0,288 ;$ & $\mathrm{r}=0,389 ;$ & - \\
\hline 3 & $\mathrm{C}-\mathrm{H}$ & $\mathrm{r}=0,290$ & $\mathrm{r}=0,285 ;$ & $\mathrm{r}=0,297 ;$ & - \\
\hline 4 & $\mathrm{C}-\mathrm{O}$ & $\mathrm{r}=-0,445$ & $\mathrm{r}=-0,432 ;$ & $\mathrm{r}=-0,465 ;$ & - \\
\hline 5 & $\mathrm{C}-\mathrm{Q}_{4}$ & $\mathrm{r}=-0,507$ & $\mathrm{r}=-0,451 ;$ & $\mathrm{r}=-0,565 ;$ & - \\
\hline 6 & $\mathrm{E}-\mathrm{F}$ & $\mathrm{r}=0,269$ & $\mathrm{r}=0,175 ;$ & $\mathrm{r}=0,360 ;$ & 0,01 \\
\hline 7 & $\mathrm{E}-\mathrm{H}$ & $\mathrm{r}=0,248$ & $\mathrm{r}=0,133 ;$ & $\mathrm{r}=0,304 ;$ & 0,01 \\
\hline 8 & $\mathrm{E}-\mathrm{L}$ & $\mathrm{r}=0,343$ & $\mathrm{r}=0,188 ;$ & $\mathrm{r}=0,245 ;$ & - \\
\hline 9 & $\mathrm{~F}-\mathrm{H}$ & $\mathrm{r}=0,431$ & $\mathrm{r}=0,371 ;$ & $\mathrm{r}=0,480 ;$ & - \\
\hline 10 & $\mathrm{~F}-\mathrm{Q}_{2}$ & $\mathrm{r}=-0,286$ & $\mathrm{r}=-0,271 ;$ & $\mathrm{r}=-0,300 ;$ & - \\
\hline 11 & $\mathrm{H}-\mathrm{Q}_{4}$ & $\mathrm{r}=-0,276$ & $\mathrm{r}=-0,225 ;$ & $\mathrm{r}=-0,337 ;$ & 0,05 \\
\hline 12 & $\mathrm{~L}-\mathrm{Q}_{4}$ & $\mathrm{r}=0,271$ & $\mathrm{r}=0,246 ;$ & $\mathrm{r}=0,293 ;$ & - \\
\hline 13 & $\mathrm{O}-\mathrm{Q}_{4}$ & $\mathrm{r}=0,406$ & $\mathrm{r}=0,388 ;$ & $\mathrm{r}=0,419 ;$ & - \\
\hline
\end{tabular}

\section{References:}

1. Cattell RB (1979) Personality and learning theory: The structure of personality in its environment, vol 1. New York: Springer

2. Cattell RB (1980) Personailty and learning theory: A systems theory of maturation and structured learning, vol. 2. New York: Springer

3. Pulkina BP (2010) A local nurse: personality traits. The Nurse, (7), pp. 10-12

4. Berebin Michael, Kondratenkov Sergey (2012) Clinical (experts) methods of psychological diagnostic in professional selection law enforcement officials (on the example of solving problems of special units). Journal "Bulletin of the South Ural State University. Series "Psychology", (19), pp. 47-57.

5. Sokolova N (2011) On the influence of student personality features on mastering a foreign language. Journal "Vestnik of Northern (Arctic) Federal University", (1), pp. 181-184.

6. Volkova ON, Sukalo AV (2001). Features of psychoemotional status of children suffering from chronic gastroduodenitis and reflux esophagitis. Journal of the Grodno State Medical University, (3), pp. 57-60.

7. Bern S (2002) Gendernaia psikhologiia [Gender psychology]. ОЛМА Media Group. 320 p.
8. Bendas TV, Bedas TV (2009) Psikhologiia liderstva. [Psychology of lidership] Publication house "Piter". $447 \mathrm{p}$.

9. Schmitt DP, Realo A, Voracek M, Allik J (2008) "Why can't a man be more like a woman? Sex differences in Big Five personality traits across 55 cultures". Journal of Personality and Social Psychology, 94 (1), pp. 168-182. doi:10.1037/0022-3514.94.1.168.

10. Smolin D, Loginova A, Voight L Psychological aspects of compilation of surgeon, therapist, pediatrician professiograms. Medical Bulletin of MIA, (2), pp. 66-70

11. Gormin AS (2010) Metodologiya I metody psikhologii. [Methodology and methods of psychology]. Uchebno-metodicheskoe posobie / A.S.Gormin.-Velikiy Novgorod; NIRO. 23 p.

12. Conn SR, Rieke ML (1994) The 16PF Fifth Edition technical manual. Champaign, IL: Institute for Personality and Ability Testing, Inc.

13. Pervin L, John O (2000) Psikhologiia lichnosti: teoriia $i$ issledovaniia. [Psychology of personality: theory and researsh.] Translated by M.S.Jamkoch'ian, editor V.S.Maguna. 607 p. 


\begin{tabular}{l|lr|ll|ll} 
& ISRA (India) & $=\mathbf{1 . 3 4 4}$ & SIS (USA) & $=\mathbf{0 . 9 1 2}$ & ICV (Poland) & $=\mathbf{6 . 6 3 0}$ \\
Impact Factor: & ISI (Dubai, UAE) $=\mathbf{0 . 8 2 9}$ & PUHЦ (Russia) $=\mathbf{0 . 2 3 4}$ & PIF (India) & $=\mathbf{1 . 9 4 0}$ \\
& GIF (Australia) & $=\mathbf{0 . 5 6 4}$ & ESJI (KZ) & $=\mathbf{1 . 0 4 2}$ & IBI (India) & $=\mathbf{4 . 2 6 0}$ \\
& JIF & $=\mathbf{1 . 5 0 0}$ & SJIF (Morocco) & $\mathbf{2 . 0 3 1}$ & & \\
\hline
\end{tabular}

